\title{
Koncept modernosti u djelu Anthonyja Giddensa
}

\author{
EImir KARADŽI \\ Prizren, Kosovo \\ karadzi82@hotmail.com
}

\begin{abstract}
U radu autor problematizira sociološke diskurse pojma modernosti kao ključnog koncepta sociološke teorije. Cilj mu je ukazati na temeljne postulate moderno ustrojenog društva, pri čemu se referira na koncept modernosti koji je u svojim djelima razvio Anthony Giddens analizirajući raznovrsne promjene u društvu, ekonomiji, politici, kulturi, religiji, znanosti i tehnici u posljednjih nekoliko stoljeća. U prvom dijelu rada autor predstavlja osnovne karakteristike predmodernog i modernog društva u kontrastu tradicije i modernosti te ustanovljivanje jednog bitno drukčijeg načina percepcije i organizacije društvenog života. Zatim se referira na glavna obilježja modernih multidimenzionalnih društvenih poredaka koja se tiču brzine i širine promjena. U nastavku su izložene Giddensove fundamentalne teorijske koncepcije modernosti: fenomenologija modernosti, nesigurnost i rizici upravljanja »Molohom« modernosti i pojam »radikalizirane modernosti«, kojim nastoji osporiti postmodernističku interpretaciju društva o istrošenosti »velikih narativa« i transformaciji iz modernog u postmoderno društvo. Zaključne misli analitički i kritički sumiraju Giddensove futurističke projekcije »utopijskog realizma« i viziju postmodernosti.
\end{abstract}

Ključne riječi: Giddens, modernost, tradicija, refleksivnost, globalizacija, rizik, radikalizirana modernost, postmodernost

\section{Uvod}

Modernost je društveno-historijski fenomen koji je u sociologiji 20. stoljeća prošao kroz različite interpretacije i čija je glavna funkcija bila dati smisao i značenje vremenu u kojem se živjelo. Tumačenja su varirala od autora do autora, ali u načelu svi su složni oko jednoga - živimo u doba jedne »nove«, neki će reći »druge«, modernosti (postmodernosti ili kasne modernosti, radikalizirane modernosti, refleksivne modernosti, hipermodernosti i slično), što je uglavnom pretpostavljalo detradicionalizaciju, sekularizaciju, individualizaciju, ekonomsku, političku i kulturnu globalizaciju te refleksivnost druš- 
tvenog života. Nekoliko generacija čovječanstva unatrag neposredni su svjedoci velikih revolucionarnih promjena kakve dotad nisu zabilježene. »Bilo to dobro ili loše, upadamo u jedan globalni poredak koji niko u potpunosti ne razume, ali čije posledice osećamo svi« (Gidens [Giddens], 2005 [2000]: 33). Globalna se ekonomija u modernom vremenu drastično promijenila od druge polovine 20. stoljeća. Obujam kapitala povećan je mnogostruko, a globalno se tržište proširilo skoro na sve dijelove svijeta. Te se promjene ne tiču samo ekonomije, kako se često pogrešno misli, nego i politike, kulture, obitelji, religije, prije svega tehnologije i masovnih komunikacija. Razina suvereniteta moderne države smanjena je, odnosi među ljudima različitih kultura poprimaju nove dimenzije, obiteljske i religijske vrijednosti su na razmeđu tradicije i modernosti, a visoka je tehnologija život učinila krajnje dinamičnim. Dakle, promjene su očite na svim područjima života.

U drugoj polovini 20. stoljeća nastale su brojne teorije tumačenja tih promjena kao skupa društvenih, ekonomskih i kulturnih faktora. Napisano je stotine knjiga koje o modernosti raspravljaju na različite načine. Primjerice, samo je britanski sociolog Anthony Giddens napisao devet knjiga koje u naslovu sadržavaju pojam »modernosti« ili »suvremenosti« (Loyal, 2003: 225-227). To je tema koja kod suvremenih sociologa nije iscrpljena, a moderni pristupi sociološkoj teoriji nisu zastarjeli, kako to tvrde postmodernistički teoretičari. Jedan od najutjecajnijih sociologa današnjice koji odbacuje tvrdnje postmodernista - da cjelokupno prosvjetiteljsko mišljenje moramo odbaciti, da za »metanaracije« više nema mjesta $i$ da je sve znanje relativno - upravo je Giddens, a njegov koncept modernosti tema je ovog rada. Giddensovo uključivanje u teorijsku debatu o modernosti s klasičnim, s jedne, i postmodernističkim sociolozima, s druge strane, predstavlja konstruktivnu kritiku obiju skupina autora i pokušaj autonomne interpretacije prirode modernosti i njezinih posljedica. Ključni koncepti njegova rada o modernosti jesu ontološka sigurnost i opasnost, povjerenje i rizik, vrijeme i prostor, ekspertni sustavi, tradicija i refleksivnost, kasna i refleksivna modernost, globalizacija i nacionalna država, refleksivna individualnost i nacionalni identitet. Sve te teme zavređuju izdvojene analize, za koje ovaj rad nema kapaciteta.

Giddens je jedan od najvećih suvremenih britanskih (i svjetskih) sociologa. Svoje je ideje izložio u 35 objavljenih knjiga koje su prevedene na više od 40 jezika (Tarifa, 2013: X). Zauzima peto mjesto najcitiranijih autora u društvenim i humanističkim znanostima i u tome je nadmašio so- 
ciološke klasike kao i suvremene sociologe (Thomson Reuters, 2009). Njegove ideje utječu na razvoj sociologije i društvenih teorija diljem svijeta. Između ostaloga, bavi se modernošću i njezinim utjecajem na individualni i društveni život i pitanjem nalazimo li se u postmodernom dobu ili dobu kraja modernosti. Istražuje teme intime, suvremenih političkih gibanja, suštine i posljedica procesa globalizacije, društva rizika i ekoloških posljedica globalnog društva. Svojim je djelima pridonio interpretaciji klasičnih i suvremenih socioloških teorija, rješavanju tradicionalnih problema analize klasa, stvaranju teorije strukturacije, teorijskoj kritici historijskog materijalizma i razvoja suvremene države-nacije. Odlika Giddensova pristupa je interdisciplinarnost - ne bavi se samo sociološkim, nego i psihološkim, antropološkim, arheološkim, filozofskim, ekonomskim, političkim i drugim problemima društva (Pajaziti, 2009: 207-209).

Dva su razloga zašto smo kao predmet ovog rada odabrali Giddensovu teorijsku analizu o implikacijama modernističkih procesa. Kao sociolog, Giddens je, bez obzira na kritike i propuste (npr., Alexander, 1996; Held i Thompson, 1989; Meštrović, 1998), vrlo utjecajan u sociološkoj teoriji, i općenito u globalnom društvu, kako smo prethodno istaknuli, i potom, on je svoju karijeru izgradio, prije svega, analizom modernosti, čemu je prethodio razvoj vlastite metode viđenja društvenih fenomena - teorija strukturacije, koja je u biti pokušaj prevladavanja mikro i makroaspekata sociološke analize. Neki ga, zajedno s Beckom, Touraineom i drugima, uvrštavaju među neomoderniste, nakon što su oni, pobijanjem postmodernističke paradigme, iznova doveli modernost u središte intelektualne rasprave. Analizom njegova koncepta modernosti želimo ukazati na ključne elemente modernog, u osnovi racionalno ustrojenog društva, od politike i ekonomije, do znanosti i tehnike i ukupne svakodnevne društvene stvarnosti.

Modernost, kod Giddensa, označava oblike društvenog života koji su se pojavili u postfeudalnoj Europi od 17. stoljeća nadalje, i čiji se utjecaj širio gotovo po cijelom svijetu (Giddens, 1991: 14-15). Kao takva, moderna društva obilježavaju industrijalizam, kapitalizam, urbanizacija i liberalna demokracija. ${ }^{1}$ Te su promjene po karakteru institucionalne i

\footnotetext{
${ }^{1}$ Dakako, modernost i njezini atributi određuju se na različite načine: »Modernost je široki idejni i praktični projekat, nastao u severnoitalijanskim renesansnim gradovima, čiji su glavni atributi - tržišna privreda, privatno vlasništvo, racionalnost i individualizam - opšta i dugo trajuća forma (i ontološki uslov njegovog postojanja), unutar koje se vrši permanentna heterogenizacija/diferencijacija delanja i, konsekventno tome, permanentna transformacija njegovih specifičnih istorijskih varijeteta« (Turza, 1998: 31).
} 
pretpostavljaju određene vrijednosne koncepte: vjerovanje u mogućnost ljudskog progresa (npr., Comte i Marx), raskid jedinstva neba i zemlje, odnosno trijumf sekularnog nad sakralnim, racionalno planiranje i birokratsko djelovanje da bi se postigli ciljevi (Weber) te vjera u slobodu i sposobnost znanosti i tehnologije da zadovolje ljudske potrebe. Jednom riječju, diskontinuitet sa svetim i božanskim, tj. raskid $\mathrm{s}$ tradicionalnim poretkom, odnosno uvriježenim normama i vrijednostima, te vjera u razum kao neprikosnovenog suca, mogu se smatrati ključnim obilježjima modernističke misli koja počiva na racionalnom mišljenju i empirijskom proračunu (Haralambos i Holborn, 2002 [1995]: 7-8, 1069). U tom smislu, važno je, iz Giddensove perspektive predstaviti osnovne značajke predmodernog i modernog društva u kontrastu tradicije i modernosti, i njegove refleksije o raskidu s tradicijom i nastanku jednog bitno drukčijeg načina percepcije i organizacije društvenog života.

\section{Binarna opozicija tradicije i modernosti}

Giddens razlikuje tri tipa predmodernih društava: lovačko-sakupljačka, stočarsko-agrarna i neindustrijske ili tradicionalne civilizacije (Gidens [Giddens], 2007 [2006]: 34-38). Predmoderna društva čine veći dio ljudske povijesti i zasnivala su se na tradiciji, običaju, religiji i praznovjerju. Zajedničko im je da su to plemenska, nerazvijena i primitivna društva, koja nisu imala veliki utjecaj na opći razvoj ljudskog društva, kao što to imaju ona moderna industrijska. Moderno doba donosi bitno drukčiji način organizacije i poimanja svijeta u odnosu na sva prethodna historijska razdoblja i društvene sustave. Modernost odlikuju veće mogućnosti individualnog izbora, nasuprot predmodernih društava koja su inherentno vezana za kolektivitet i tradiciju. Tradicija je »konzervativna«, »nazadna«, »zatvorena« i »neupitna«. U društvu u kojem dominira tradicija, u kojem su stavovi, ponašanja i institucije pod utjecajem tradicionalnih obrazaca, ponašanje pojedinca determinirano je običajem i navikama, i njegove su mogućnosti slobodnoga racionalnog izbora ograničene (Coser, 2005 [1964]: 375). Te ideje tvore polaznu osnovu Giddensove teorije o samoidentitetu, izložene $\mathrm{u}$ djelu sociopsihološke prirode Modernity and Self-Identity (1991), u kojem analizira promjene u osobnom životu te stanje sebstva i međuljudskih odnosa u suvremenom društvu.

Giddens primjećuje da je tradiciju i njezinu društvenu ulogu snažno diskreditiralo europsko prosvjetiteljstvo (Gidens [Giddens], 2005 [2000]: 
64). Identificirana je s dogmom i neznanjem, i u konačnici kvalificirana antipodom modernosti. Iako nije njezin obožavatelj, Giddens zastupa jedan sasvim oprezniji pristup tradiciji. On se zalaže za oslobađanje od prosvjetiteljskih predodžbi i iluzija o uništenju autoriteta tradicije. Bez obzira na to što je autoritet tradicije u modernom dobu ozbiljno poljuljan, jer su tradicionalne vrijednosti dobrim dijelom ustuknule pred naletom modernosti, prema Giddensovom mišljenju, »sasvim je racionalno priznati društvenu potrebu za tradicijama«, koje su još uvijek vrlo snažne u najvećem dijelu svijeta jer one će uvijek »opstajati zato što životu daju kontinuitet i formu« i kao takve će se u modernom društvu »održavati u meri u kojoj se mogu efikasno opravdati«, uglavnom u smislu inercije ili navike (Gidens [Giddens], 2005 [2000]: 70-71).

Iako tradicija ne isključuje nužno modernizaciju, čemu svjedoči uspon azijskih privreda, Giddens se, ipak, zalaže za detradicionalizaciju, za jedno novo, nastajuće - »globalno kozmopolitsko«, demokratsko, liberalno, individualističko, progresivno, otvoreno i kritičko - društvo (Gidens [Giddens], 2005 [2000]: 68). U takvom jednom društvu, »više nitko nije arbitar našega osobnog razvitka ili našeg života osim nas samih. Ne postoji to mjerilo na koje bi nas netko u vrijeme modernosti mogao pozvati, nema te vrijednosti ili moralnog propisa koja je uvriježena toliko općenito da bi mogla neupitno vrijediti za sve« (Zlatar, 2008: 164). Upravo u toj lišenosti odgovornosti suvremenog čovjeka osim samome sebi i svojoj savjesti treba tražiti odgovor na brojne probleme i izazove suvremenog svijeta. Na tom tragu, francuski sociolog Alain Touraine u mnogo radikalnijem tonu nego Giddens kritizira modernost i modernističku ideologiju. On opisuje razvoj modernosti u zapadnoj hemisferi, osobito u Francuskoj, kao »borbu protiv tradicionalnog društva«, revoluciju k »racionalnom društvu« i »trijumf uma«. Kad govori o tradiciji, religiji i modernosti, Touraine ističe da moderno društvo u svom identitetu mora baštiniti tradicijska i religijska načela, dok god se primjenjuje načelo razdvajanja svjetovnog i duhovnog autoriteta, a ne samo suštu volju za slobodom i pokornost zahtjevima racionalne misli. Također, on je decidiran da modernost ne smije predstavljati prekid sa svetim, odnosno da se modernost ne treba definirati »kao prijelaz sa svetog na racionalno«, kako se često misli, »u smislu trijumfa svjetla uma nad iracionalnosti vjerovanja« (Touraine, 2007 [1992]: 243). To ne implicira ideju za revitalizaciju religije i posvećenje ili pak sekularizaciju društva, nego tipičnu značajku nemo- 
gućnosti da se moderno društvo poistovjeti s određenim sustavom vrijednosti, društvenih normi i vjerovanja. Većina je zemalja u modernizaciju išla različitim putevima. Takva su paradigma Sjedinjene Američke Države i njihova politička kultura baštinjenja religijskih vrijednosti i kulture zapadne Europe koje su većim dijelom pod utjecajem nacionalizma. U neki dijelovima svijeta širenje modernosti prouzročilo je »kulturnu zbrku« (Nasr, 2001 [1968]: 193), jer su tradicije još uvijek bile žive i moćne.

\section{Središnja obilježja modernosti}

Institucionalnu analizu modernosti Giddens je začeo u djelu The Consequences of Modernity (1998 [1990]). U drugim dvama djelima, Modernity and Self-Identity (1991) i The Transformation of Intimacy (1992), koja su nastala neposredno nakon toga, on je, obradivši teme identiteta, samoidentiteta, intimnosti, seksualnosti i ljubavi, zaokružio teoriju modernosti. $\mathrm{Na}$ početku autor raspravlja o »diskontinuitetima modernosti« i razvija diskontinuiranu interpretaciju razvoja životnih oblika modernog društva. On ushićeno izjavljuje: »Životni oblici koje je donela modernost uklonili su sve tradicionalne tipove društvenog poretka, na način koji nikada ranije nije bio zabeležen« (Gidens [Giddens], 1998 [1990]: 16). Giddens tvrdi da $\mathrm{u}$ usporedbi s tradicionalnim društvima, moderne društvene poretke odlikuju tri obilježja: a) brzina promjena, koja, u modernim društvima postaje iznimnom, a koja se osobito ističe u tehnološkim promjenama; b) domet i širina promjena, koje postaju globalnima i obuhvaćaju gotovo cijelu zemaljsku kuglu; i c) različita unutarnja priroda modernih institucija, što najbolje ilustriraju razlike koje je moderni urbanizam unio između predmodernog i modernog grada (Gidens [Giddens], 1998 [1990]: 17; Pavlović, 2009: 34-35). Upravo su te promjene u modernosti polučile određene procese koje nije poznavalo predmoderno doba: distancijaciju (proces razdvajanja prostora i vremena), povjerenje u ekspertne sustave, refleksivnost i globalizaciju.

\subsection{Distancijacija - proces razdvajanja prostora i vremena}

Vremensko-prostorno distanciranje uvjetovano je postojanjem »praznog vremena« (mehanički satovi, datumsko vrijeme) i »praznog prostora« (mape svijeta). Giddens moderno doba uspoređuje s predmodernim epohama kad su prostor i vrijeme uvijek bili vezani za mjesto, odnosno za scenu kojoj istodobno prisustvuju društveni akteri koji su u neposrednoj 
interakciji licem u lice (Neš [Nash], 2006 [2000]: 78). Taj lokalni okvir zamijenjen je globalnim poimanjem prostora i vremena, gdje se sve više prekida veza između prostora i vremena. Pojednostavljeno, u suvremenosti nije neophodno da određeni akter geografski bude blizu nečega da bi na nešto izvršio nekakav utjecaj. Na primjer, nuklearna podmornica goleme razorne moći može biti udaljena tisućama kilometara od onih koji njome upravljaju. Ili pak tehnološke inovacije, poput interneta, smanjile su vrijeme potrebno za komuniciranje i omogućile su virtualnu interakciju među ljudima. Dakle, ti su procesi pridonijeli pojavi različitih vrijednosti, pokreta i institucija, koje u predmodernim vremenima nisu postojale. Novac, kao simboličko znamenje, jedan je takav društveni oblik. Čovjek ne mora biti na istom mjestu na kojem su i njegove vrijednosti. Novac omogućuje razmjenu dobara i usluga (npr., bankarske transakcije ili internetsko plaćanje) među subjektima koji se međusobno ne poznaju ili su udaljeni tisućama kilometara.

\subsection{Povjerenje u ekspertne sustave}

Zbog istaknutih promjena u prostoru i vremenu, suvremeni je čovjek primoran da razvije povjerenje $u$ sustave i eksperte koji te sustave kontroliraju i njima upravljaju. Povjerenje je glavni aspekt društvenog života koji ne iziskuje definitivno znanje. Zapravo, modernost mijenja temelj na kojem se gradilo povjerenje. Umjesto prema određenom pojedincu, $\mathrm{u}$ modernosti povjerenje ulažemo u ekspertne sustave koji podučavaju ljude te nadziru i reguliraju njihovo ponašanje. Na primjer, ne moramo osobno poznavati pilota prije nego što uđemo u avion. Vjerujemo da je pilot osposobljen za upravljanje avionom. Dakle, mi na potencijalni rizik odgovaramo povjerenjem u njegovu kompetenciju. U protivnom, suvremeno društvo ne bi bilo moguće (Ricer, 2009: 206). Giddens smatra da su ekspertni sustavi (inženjeri, arhitekti, liječnici, pravnici, psiholozi ili znanstvenici) važan mehanizam iskorjenjivanja (disembedding mechanisms) (Loyal, 2003: 116) i definira ih kao »sisteme tehničkih postignuća ili profesionalne ekspertize, koji organiziraju velika područja materijalnog i društvenog okruženja u kojem danas živimo« (Gidens [Giddens], 1998 [1990]: 35). Ekspertni sustavi omogućuju da se mnogi aspekti društvenog života zbivaju, a da se pritom ne iskaže potreba za neposrednim kontaktima među akterima uključenim u te procese. Suvremeni ljudi mogu izvoditi svoje dnevne aktivnosti, a da ne moraju znati detalje tih aktivnosti. 
Recimo, pacijent može biti operiran u kardiovaskularnoj klinici, a sam ne znati kako se to izvodi.

\subsection{Refleksivnost}

Osim spomenutih mehanizama iskorjenjivanja, ključno obilježje modernosti, odnosno njezin imanentni dio, jest sve veća refleksivnost. »Refleksivnost modernosti« kod Giddensa označava proces koji sve naše postupke $\mathrm{u}$ društvenom životu podvrgava preispitivanju, reviziji i modifikaciji, i nastoji ih poboljšati. »Refleksivnost modernog društvenog života sastoji se u činjenici da se društvene prakse neprestano ispituju i menjaju, u svetlu novih informacija o samim tim delatnostima, tako da se njihove karakteristike sadržinski menjaju« (Gidens [Giddens], 1998 [1990]: 45). U predmodernim vremenima, refleksivnost je bila ograničena tradicijom. Tradicija je dogmatski nalagala i određivala kako će se ljudi ponašati i djelovati. U modernom dobu, tradicija gubi tu ulogu, ona biva gurnuta u stranu, dogma biva zamijenjena prosvijetljenim umom, a refleksivnost postaje normom. Giddens tvrdi da se suvremene institucije razlikuju od tradicionalnih oblika društvenog života po svom dinamizmu i stupnju odbacivanja tradicionalnih običaja i navika (Haralambos i Holborn, 2002 [1995]: 496, 1076). Moderno je društvo »refleksivno«, sve je sposobnije djelovati samo na sebe, nadzirati, samoproizvoditi, samopromatrati i samoregulirati vlastite akcije, što ga umnogome razlikuje od predmodernih društava u kojima se preko tradicije uspostavlja izravan odnos pojedinca i društva (Zlatar, 2008: 165).

Refleksivna modernost nije samo potkopala tradiciju, nego i samu znanost, odnosno refleksivno primijenjeno znanje, koje je u modernosti podložno preispitivanju i revidiranju u uvjetima trajnih promjena društvenih praksi. Giddens apostrofira da modernost podriva svaku izvjesnost, pa i znanstveno znanje koje pruža najpouzdanije informacije o svijetu. Eksplicitno ističe da »u nauci ništa nije izvesno i ništa se ne može dokazati« jer »sve društvene nauke učestvuju u tim refleksivnim odnosima« (Gidens [Giddens], 1998 [1990]: 46-47), a sociologija među njima zauzima središnje mjesto.

$\mathrm{U}$ kontekstu refleksivne modernosti Giddens se u djelu Modernity and Self-Identity bavi pitanjem subjektivnosti i osobnog identiteta. Ističe da su u tradicionalnim kulturama u stvaranju ličnosti, identiteta i ponašanja ključnu ulogu imale tradicija, kulturna sredina u kojoj smo rođeni i reli- 
gijski moralni kodovi. Obrisi kulture prenosili su se s koljena na koljeno. Pripadnost nekoj široj društvenoj skupini, etničkoj ili nacionalnoj, fiksirala je naš osobni identitet. Ljudi su se nastojali prilagoditi društvenoj sredini, bez pretenzija za njezinim oblikovanjem. U »posttradicionalnom društvu« identiteti se manje nasljeđuju, a više se stvaraju kroz "procese samoizražavanja « i interakcije s drugim akterima. ${ }^{2}$ Samoidentitet nije nešto dano, nego nešto što kao rutina nastaje i održava se kroz refleksivno djelovanje pojedinca (Giddens, 1991: 52). Identiteti su danas raznovrsni, fragmentirani, pa i proturječni. Izvori identiteta kao što su rod i seksualna orijentacija dobili su veću ulogu, a kreiranje novih identiteta lakše je nego ikada. Sada pojedinac aktivno sudjeluje u oblikovanju i mijenjanju svijeta. Ipak, ti su identiteti labilni i krhki.

Refleksivnost suvremenog čovjeka u određenom smislu determinira sve ljudske aktivnosti u kojima se odvija društveni život, pa tako i odnos prema samima sebi i vlastitom životu. Svijest i ponašanje Giddens dovodi u vrlo integrativan odnos. Sebstvo postaje refleksivan projekt (Giddens, 1991: 32). Akteri su svjesni sebe i svog ponašanja (refleksivni nadzor djelovanja) i s njim ostaju u vezi. Ti odnosi nisu mehaničkog, nego vrlo racionalnog karaktera, u smislu da su društveni akteri refleksivni, tj. da nadziru sebe i svoje ponašanje i permanentno ga preispituju, što se ne manifestira samo na svakodnevne društvene prakse, nego i na osobni identitet i biografiju pojedinca. To je pojedinac koji traga za samoidentitetom. Taj tip refleksivnosti Giddens naziva »refleksivnom projekcijom osobnosti«, gdje pojedinci ne samo da nadziru svoje ponašanje, nego imaju mogućnost da ponekad izmijene ili potpuno promijene vlastito djelovanje zahvaljujući ovladavanju ekspertnim znanjima. Rezultat toga je »trajektorij osobe, dinamička igra između prošlosti, sadašnjosti i očekivane budućnosti« (Zlatar, 2008: 169-170).

Refleksivnost podrazumijeva i neprestano razmišljanje aktera o individualnim i globalnim opasnostima koje ugrožavaju njihov život, posebno nuklearna tehnologija i genetski inženjering. Ta bojazan u ljudima konstantno izaziva osjećaj nelagode, što dovodi do stanja anksioznosti i stalnih

2 Giddens je, nešto kasnije, nakon teorije modernosti, razvio koncept novog tipa društva, »posttradicionalnog društva«. Zahvaljujući procesima globalizacije i individualizacije, mnogi su se aspekti društvenog života detradicionalizirali, odnosno tradicija je za pojedinca kao referentni okvir djelovanja samo jedna od alternativa njegova izbora. To ne implicira potpuni nestanak tradicije, nego njezino svođenje na stalno preispitivanje (Giddens, 1994: 100). 
promjena. Ljudi su sve spremniji mijenjati svoje običaje, uvjerenja, prakse i institucije kako bi se prilagodili novim spoznajama.

\subsection{Globalizacija}

Tema globalizacije je kao rijetko koja, vjerojatno zbog svojih posljedica, privukla akademsku pozornost brojnih autora. Kao alternativu marksističkom shvaćanju, Giddens i njemački sociolog Ulrich Beck razvili su shvaćanje »globalizacije kao modernizacije« u okviru sociologije refleksivnosti. Modernost radikalno transformira svijet i ona je, prema Giddensu, »inherentno globalizirajuća«. Tako se globalizacija može shvatiti kao »intenzifikacija društvenih odnosa na svetskom planu, koja povezuje udaljena mesta na takav način da lokalna zbivanja uobličavaju događaji koji su se odigrali kilometrima daleko i vice versa« (Gidens [Giddens], 1998 [1990]: 69). Isto tako, mehanizmi iskorjenjivanja i refleksivnosti omogućili su da se društveni život sve više oblikuje prema događajima koji se zbivaju na udaljenim mjestima.

Giddens navodi četiri osnovne dimenzije globalizacije: svjetska kapitalistička ekonomija, sustav nacionalnih država, svjetski vojni poredak i međunarodna podjela rada. Kao središnju dimenziju globalizacije odbacuje tradicionalno marksističko i neomarksističko poimanje da je globalizacija determinirana isključivo jednim uzrokom - ekonomskom dimenzijom, odnosno da je ona posljedica »kapitalističkog svjetskog sistema« (Volerstin [Wallerstein], 2005 [2004]) i smatra da su moderne transformacije više posljedica dinamizma modernog doba (Neš [Nash], 2006 [2000]: 78), gdje je svjetska kapitalistička ekonomija (uobličena u formi transnacionalnih korporacija) samo dio multidimenzionalnosti globalizacije. Na tom tragu Beck, kao relevantniji izvor saznanja o logici globalizacije, razvija koncept »globalizma ${ }^{3}$ i tvrdi da se neomarksistička »ekonomska globalizacija miješa s internacionalizacijom ekonomije«, odnosno da »ne može biti govora o globalizaciji, već o internacionalizaciji« (Beck, 2003 [1997]: 275). Po njemu, globalizacija nije isključivo posljedica »ekspanzivnog kapitalizma« koji, potkopavajući temelje nacionalne države (tj. političkog poretka), razvija nove globalne obrasce eksploatacije zahvaljujući moći koju proizvodi, nego

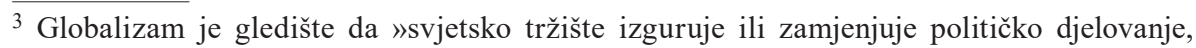
odnosno ideologiju vladavine svjetskog tržišta, ideologiju neoliberalizma« (Beck, 2003 [1997]: 24). Beck takvo shvaćanje, da svjetskim tržištem dominira kapitalistička ekonomija, kritizira i ističe da, osim ekonomske osnove, globalni razvoj determiniraju politika, ekologija, kultura i civilno društvo.
} 
da je globalizacija multidimenzionalan pojam koji osim najdiskutiranije ekonomske dimenzije - oličene u »svjetskom društvu« koje nadilazi nacionalne države i nacionalne ekonomije - podrazumijeva kulturnu, ekološku, komunikacijsko-tehničku, radno-organizacijsku i građansko-društvenu dimenziju (Beck, 2003 [1997]: 46). Povrh svega, u dobu globalizacije, nacionalne se države, kao glavni akteri globalnoga političkog poretka, moraju pomiriti s činjenicom opadanja, odnosno prenošenja dijela suvereniteta na globalne agencije, u korist razvijanja obrazaca međusobne ovisnosti i uspostavljanja multilateralnih političkih, ekonomskih i vojnih odnosa na međunarodnoj areni (Ujedinjeni narodi, NATO savez, Europska unija i tako dalje).

\section{Multidimenzionalnost institucija modernosti}

Još jedno važno obilježje Giddensove teorije modernosti pitanje je njezine institucionalne dimenzionalnosti. Klasični teoretičari modernosti poput Marxa, Durkheima i Webera tumačenjem suvremenoga razvijenog društva stvarali su jednodimenzionalne, monističke i redukcionističke sociološke teorije, naglašavajući samo jednu dominantnu institucionalnu dimenziju modernosti. Marx je naglašavao isključivo kapitalističku dimenziju modernog društva. Durkheim je smatrao da je moderno društvo industrijsko i da će difuzija industrijalizma dovesti do harmoničnoga društvenog života, dok je Weber smatrao da je ono birokratsko i da taj sustav upravljanja razvijen u kapitalizmu, praćen tehnološkim napretkom, predstavlja najsavršeniji i najracionalniji oblik društvene organizacije (Tarifa, 2013: XII). Za razliku od njihovih promišljanja, Giddensova hipoteza se zasniva na uvjerenju da je modernost, na nivou institucija, multidimenzionalna. On smatra da se modernost temelji na četirima institucionalnim dimenzijama (Gidens [Giddens], 1998 [1990]: 61-64; Haralambos i Holborn, 2002 [1995]: 646, 1076-1077):

a) Kapitalizam je središnja tema socioloških teorija koje su kritički razvili marksistički teoretičari. Giddens kapitalizam definira kao akumulaciju kapitala u uvjetima konkurencije na tržištu rada i proizvodnje. U prirodi je kapitalizma odnos između privatnog vlasništva nad sredstvima za proizvodnju i najamnog rada, i taj odnos čini glavnu osnovu klasnog sustava (Gidens [Giddens], 1998 [1990]: 61). Budući da je kapitalistički sustav ekspanzionistički i konkurentan, prirodno je da njegovi akteri uvijek traže nova tržišta i pokušavaju proizvesti nove proizvode kako bi stekli profit. To pridonosi razvoju globalizacije i širenju modernosti; 
b) Industrijalizacija podrazumijeva iskorištavanje neživih izvora materijalne moći u proizvodnji dobara, gdje središnju ulogu imaju tehnički strojevi u proizvodnom procesu. Njezin početak datira od 18. stoljeća, odnosno prve industrijske revolucije, a potom se širi na veći dio Europe;

c) Administrativni nadzor i kontrola procesi su koji daleko premašuju sposobnosti i mogućnosti tradicionalnih civilizacija. U doba modernosti, država je razvila cijeli niz sustavnih tehnika za nadziranje populacije (zatvori, bolnice, škole, tvornice) s ciljem kontroliranja informacija i ponašanja ljudi; ${ }^{4}$

d) Vojna sila je četvrta institucionalna dimenzija koja odlikuje modernu u odnosu na predmodernu državu. Moderna država unutar svojih teritorijalnih granica vrši monopol nad sredstvima prinude. Od Prvoga svjetskog rata pa do danas, vojna tehnologija je učinila da se u ratovima koristi sve veća destruktivna moć koja ima globalni karakter.

\section{Fenomenologija modernog svijeta}

Iako se svrstava u istaknute moderniste, Giddens drukčije percipira fenomenologiju modernog svijeta i život u njemu od klasičnih teoretičara modernosti. On najprije raspravlja o dvjema teorijama modernosti koje su dominirale u sociološkoj literaturi,: Marxovoj i Weberovoj (Loyal, 2003: 117), koje su u osnovi radikalne i kritičke. Marx je davno osnovno obilježje modernosti, kapitalizam, nazvao »monstrumom«, »čudovištem«, koje eksploatira proletarijat i narodne mase. »Kapitalizam je, jednostavno, iracionalan način da se upravlja modernim svetom, jer on nameće hirove tržišta umesto kontrolisanog zadovoljavanja ljudskih potreba« (Gidens [Giddens], 1998 [1990]: 134). Weber je smatrao da nas sve više racionalizirajuća modernost zatvara u »čelični kavez birokratske racionalnosti« (Haralambos i Holborn, 2002 [1995]: 1077). Giddens i jedno i drugo stajalište odbacuje i nudi vlastitu interpretaciju modernosti. Premda nije zauzeo tako radikalan stav poput Marxa i Webera, on smatra da modernost nije integrirana cjelina, nego se sastoji od vrlo kontradiktornih dijelova. On navodi četiri dijalektič-

\footnotetext{
${ }^{4}$ Ovdje se Giddens dotiče koncepta biopolitike, odnosno sistemskog upravljanja i kontrole nad populacijom od strane vlasti, razvijenog u djelima Rađanje biopolitike i Nadzor i kazna francuskoga postmodernističkog društvenog filozofa Michela Foucaulta (Fuko [Foucault], 2005 [1978], 1997 [1975]), velikog kritičara suvremenih društvenih institucija. Baveći se temama zločina, tijela, ludila i seksualnosti, Foucault je analizirao pojavu modernih institucija poput zatvora, bolnica i škola, koje imaju sve veću ulogu u kontroliranju i nadziranju društvene populacije.
} 
ka okvira modernosti koje izvodi iz dijalektike prostora i vremena (Gidens [Giddens], 1998 [1990]: 135-143; Zlatar, 2008: 163):

a) Dislokacija naspram ponovne integracije: presjek otuđenja i bliskosti. Vremensko-prostorna organizacija modernosti, zahvaljujući razvoju suvremenih tehnologija, na nevjerojatan način spaja blizinu i daljinu, što omogućuje da su bliskost i mjesto mnogo manje povezani nego prije, a da je otuđenje od lokalnog veće nego u predmodernim vremenima. Osoba koja komunicira s drugom osobom udaljenom tisućama kilometara možda je s njom u bliskijem odnosu nego s nekim od svojih ukućana;

b) Intimnost naspram impersonalnosti: presjek osobnih i impersonalnih veza okviri su koje je Giddens šire obradio u djelu The Transformation of Intimacy (1992). On smatra da su u visokoj modernosti intimni odnosi među ljudima drukčiji. Ranije se u brak stupalo zbog reprodukcije i ekonomskih odnosa. Nakon 18. stoljeća razvija se ideal »romantične ljubavi« i ta se veza zasnivala na uzajamnoj privlačnosti. Iz toga se kasnije razvila »nova seksualnost« (plastic sexuality) koja mijenja i samu narav ljubavi, gdje je spolni odnos oslobođen imperativa reprodukcije (Giddens, 1992: 27, 38). Preobrazbu intimnosti omogućavaju apstraktni sustavi koji nas, unatoč udaljenosti, svakodnevno intimno povezuju. U predmodernim okvirima intimni odnosi i interakcije među ljudima zasnovale su se na poznatosti i bliskosti. Udaljenost danas tomu nije prepreka;

c) Stručnost naspram ponovnog prilagođavanja: presjek apstraktnih sustava i znanja koja se svakodnevno stječu. Giddens se ne slaže s Habermasovim stavom da apstraktni sustavi koloniziraju »svijet života« podvrgavajući osobne odluke tehničkoj ekspertizi. Iluzorna je pomisao da $\mathrm{u}$ modernim okvirima izuzetno složenog sustava znanja pojedinac, oslobođen mistike i neznanja, u uvjetima suvremenih tehnologija može ponovo ovladati pojedinim područjima znanja. Stručni sustavi pojedincu omogućavaju stjecanje potrebnih znanja za funkcioniranje u suvremenom društvu (Zlatar, 2008: 163);

d) Privatnost naspram zauzimanja: presjek pragmatičnog prihvaćanja i aktivizma. Pragmatično prihvaćanje predstavlja svijest o nemoći pojedinca (pasivizam) da u modernom dobu na bilo koji način utječe na rizike $\mathrm{s}$ teškim posljedicama. Međutim, moderno društvo ne bi bilo moguće da nije razvijen sustav povjerenja u ekspertne sustave, odnosno uvjerenje $u$ dalje postojanje svijeta. Ipak, budući da se ovaj svijet tiče nas, koji smo 
njegov imanentni dio, uvjeti modernosti izazivaju aktivizam, protest i angažman, zato što je refleksivnost kao imanentni dio modernosti polučila različite oblike radikalnog aktivizma, konkretnije, društvene pokrete »kao važnu liniju vodilju za potencijalne buduće preobražaje« (Gidens [Giddens], 1998 [1990]: 152).

Iz izloženog se može zaključiti da modernost ima vrlo ambivalentan karakter. Ona u životu ljudi otvara nove mogućnosti koje u predmodernim društvima nisu postojale, ali sa sobom donosi i velike rizike i opasnosti (Gidens [Giddens], 1998 [1990]: 163). ${ }^{5}$ Rast totalitarne moći proizlazi iz sustava nadziranja koji modernoj državi omogućuje jaku kontrolu populacije, a kolaps mehanizama ekonomskog rasta proizlazi iz nepredvidljivosti i ranjivosti kapitalističkog sustava. Potencijalni nuklearni sukobi globalnog ratovanja poslije Hirošime i Nagasakija opsesivno zaokupljaju pozornost sve većeg broja ljudi i izazivaju »strah od nepostojanja« (Gidens [Giddens], 1998 [1990]: 141) ne samo pojedinaca nego ukupne ljudske vrste, civilizacije i prirode. Globalno zatopljenje i ekološke katastrofe ozbiljno su ugrozile budućnost života na Zemlji. Najkraće rečeno, u okrilju modernosti su po prvi puta u povijesti stvoreni uvjeti za potpuno i nepopravljivo uništenje života na Zemlji. Ona nije samo okvir fantastičnih prigoda, što se odveć naglašava, nego i »generator otuđenja, postvarenja, eksploatacije velikih grupa ljudi, zatim iscrpljivanja i zagađivanja prirode itd.» (Turza, 1998: 10). Giddens modernost opisuje na jedan prilično apstraktan način. Modernost je metafora za »Moloha«, odnosno snažnu silu koja, krećući se naprijed, ruši sve pred sobom (eng. juggernaut). Što, zapravo, on želi reći tom metaforom i opasnostima koje ona nosi? Ljudi upravljaju »Molohom«, ali s obzirom na njegovu veličinu i snagu, oni ne mogu potpuno kontrolirati pravac kojim će se on kretati, niti brzinu koju će dostići. Uvijek postoji mogućnost da ljudi izgube kontrolu nad »Molohom« $\mathrm{i}$ da sve ono što je u njemu ili u njegovoj blizini bude uništeno. Onima koji ga kontroliraju, kao i onima koji mu se nađu na putu, Moloh može donijeti velike dobrobiti, ali i velike opasnosti, uključujući i stalan strah da oni koji njime upravljaju u svakom trenutku mogu izgubiti kontrolu i tako dovesti u opasnost živote mnogih ljudi. U modernosti, taj osjećaj ontološke izvjesnosti i egzistencijalne anksioznosti permanentno je u ambivalentnom odnosu (Gidens [Giddens], 1998 [1990]: 134; Ricer [Ritzer], 2009 [2006]: 205). Pritom se nameće vrlo legitimno

\footnotetext{
${ }^{5}$ Rizik predstavlja kontrolirane, a opasnost nekontrolirane posljedice u suvremenom društvu. 
pitanje: zar moderni čovjek vođen prosvjetiteljskim »načelom uma« i drugim zahtjevima racionalne i sekularne misli, kojima se tobože oslobodio praznovjerja i neznanja, nije duboko zakoračio u opasne avanture i potencijalno velike katastrofe na koje Giddens, ali i mnogi drugi, ${ }^{6}$ ukazuju? Već artikulirane posljedice modernosti nužno nas dovode do zaključka da i dalje živimo u rizičnom društvu, koje je još i masovno i visokotehnizirano. Iako je pojam rizika sustavno razvijen, kao jedna od bazičnih odrednica moderne (post)industrijske civilizacije i središnji koncept sociološke teorije, gdje je dobio svoj potpuniji teorijski i metodološki okvir u Beckovu ${ }^{7}$ djelu, posve je izvjesno da se taj pojam proteže gotovo kroz cijeli Giddensov teorijski opus, pa ćemo ga zbog toga u nastavku i koncizno izložiti.

\section{Rizik - strukturni element modernosti}

Modernost u naše živote unosi velike rizike i hazarde kojima smo svakodnevno izloženi. Giddens, na tragu Becka, ističe da države u kasnoj modernosti, u epohi globalizacije - koja radikalno mijenja naš svijet - uglavnom nemaju vanjskih neprijatelja, nego se suočavaju s novim rizicima i opasnostima (Gidens [Giddens], 2005 [2000]: 9), sofisticiranijim, i prijašnjim generacijama ljudi nepoznatim. Prijašnje su generacije imale vrlo specifične i očekivane rizike. Najčešće su se odnosili na prirodne nesreće i nepogode, poplave, oluje, suše, neplodne godine, požare, zemljotrese, glad, kugu, visoke razine smrtnosti djece i slično. Tu vrstu rizika Giddens naziva »izvanjskim«, tradicionalnim, odnosno prirodnim rizikom koji je sastavni dio sudbine svakog društva.

On govori o kvalitativno drukčijem, »novom profilu« rizika koji donosi moderni društveni život. Taj rizik ne potječe iz svijeta prirode, nego od re-

\footnotetext{
${ }^{6}$ Nietzsche i Freud, preteče postmodernističke misli, razvili su različite teorije oslobađanja čovjeka od implikacija modernističke ideologije. Za Horkheimera i Adorna modernost postaje "pomračenje uma«, a prema Touraineu ona je u krizi jer se kao ideja istrošila, kultura je zanemarena i nametnuta je ideja društva kao cjeline koja kolektivno misli i djeluje (Touraine, 2007 [1992]: 81-83).

${ }^{7}$ Ulrich Beck, njemački sociolog, u svojem je najpoznatijem djelu Rizično društvo (2001 [1986]) suvremeno društvo predstavio kao definirano rizikom i načinima na koje se rizik može spriječiti, minimalizirati ili kanalizirati. Beck smatra da se tradicionalna industrijska klasna struktura modernog društva raspada i da globalizacija proizvodi rizike za sve klase. Ipak, rizik je stratificiran i češće pogađa siromašna društva i niže klase. Bez obzira na to, čak ni viši slojevi ne mogu biti lišeni rizika suvremenog društva. On im se često vraća kao efekt bumeranga. Prema tome, nitko se ne može spasiti od rizika u rizičnom društvu, zaključuje Beck (Bek [Beck], 2001 [1986]).
} 
fleksivne modernosti, odnosno intervencije znanja i tehnologije u svijet prirode. ${ }^{8}$ Nasuprot »prirodnom« stoji »proizvedeni« rizik, dok neki teoretičari govore i o drugim podjelama rizika u tehnologiziranom svijetu. ${ }^{9}$ Proizvedeni je rizik globalizirajući i prijeti bogatima i (mnogo više) siromašnima, svim klasama i svim društvima manjim ili većim intenzitetom. Izvanjski je rizik zamijenjen proizvedenim rizikom koji je visoke vjerojatnosti, odnosno predstavlja veću prijetnju. Proizvedeni rizici po karakteru mogu biti globalni (potencijalni nuklearni rat, ekološki rizici, globalne klimatske promjene, recesija i kolaps svjetske ekonomije, naftna kriza i terorizam) i individualni (rizici po život i zdravlje, rizici od genetički modificirane hrane, rizici po brak i obitelj, zarazne bolesti i slično). Giddens je na stanovištu da umanjivanje njihovih opasnosti treba biti naš generalni cilj, a da bi se to ostvarilo, za početak, moraju se postaviti »određene granice globalne kapitalističke akumulacije« (Gidens [Giddens], 1998 [1990]: 163).

Mnogi su današnji rizici prije svega proizvod industrijaliziranog svijeta, gotovo konsenzualno ističu suvremeni sociolozi, ${ }^{10} \mathrm{i}$ ono što ih čini jedinstvenim nije samo to što prostorno i vremenski nisu ograničeni, ${ }^{11}$ nego $\mathrm{i}$ to što su opasniji nego ikad ranije. Živimo u »globalnom vojnom poretku« u kojem je destruktivna moć visokosofisticiranog oružja enormno velika, ističe Giddens, i dodaje da je mogućnost ekološke katastrofe vrlo stvarna. Ali, ono u što nema dvojbe jest činjenica da je taj rizik, globalni ili in-

${ }^{8}$ Giddens upozorava da bi znanost i tehnologiju bilo pogrešno smatrati neprijateljima svijeta prirode, jer da nije bilo znanstvenih i tehnoloških inovacija, mi čak ne bismo bili ni svjesni ekoloških problema (Gidens [Giddens], 2009 [2007]: 192).

${ }^{9}$ Hrvatski sociolog Ognjen Čaldarović pravi diobu rizika na prirodne i tehnološke. Prvi su »samoprepoznatljivi, vidljivi, [...] oni se prihvaćaju kao 'zadane' činjenice koje jednostavno postoje i koje ne treba posebno tumačiti«. Tehnološki rizici proizvod su ljudske djelatnosti, upotrebe i primjene različitih tipova tehnologija svojstvenih industrijskoj civilizaciji (Čaldarović, 1995: 23).

${ }^{10}$ Beck razlikuje tri vrste globalnih opasnosti koje prijete »svjetskom rizičnom društvu«: 1. bogatstvom uvjetovano ekološko uništenje i tehnološko-industrijske opasnosti (ozonske rupe, efekt staklenika, genetski inženjering i reproduktivna medicina), 2. siromaštvom uvjetovano ekološko uništenje i tehnološko-industrijske opasnosti (sječa tropskih prašuma, otrovni otpad) kao posljedica započetoga, a nedovršenog procesa modernizacije te 3. opasnosti oružja za masovno uništenje (nuklearno, kemijsko i biološko) (Beck, 2003 [1997]: 96-99).

${ }^{11} »$ Nuklearna katastrofa, kao ona u Černobilu 1986., nije bila ograničena samo na geografski prostor u blizini centrale, već je pogodila mnoge delove sveta od kojih su neki bili prilično udaljeni od mesta nesreće. Osim toga, posledice te nesreće nisu bile ograničene samo na vreme kada se nesreća dogodila. Ljudi i danas osećaju posledice izloženosti radijaciji, pri čemu se kod nekih ljudi javljaju novi simptomi« (Ricer [Ritzer], 2009 [2006]: 208). 
dividualni, rezultat procjene o »pretjeranoj antropocentričnoj usmjerenosti dosadašnjeg razvoja čovječanstva« (Čaldarović, 1995: 246). Njega je svojim djelovanjem prouzročio čovjek ili je čovjek u najmanju ruku pridonio njegovom nastanku, jer su »vrlo malobrojni aspekti našeg prirodnog materijalnog okruženja koji na neki način nisu pogođeni ljudskom intervencijom« (Gidens [Giddens], 2005 [2000]: 53).

Znači li to da gubimo kontrolu nad svijetom koji se sve više globalizira? Ljudi sami svojim djelovanjem proizvode društveni svijet, ali nisu u stanju potpuno ga kontrolirati. Ta je kontrola slaba i permanentno je otvorena mogućnost katastrofe koja može biti, u najgorem slučaju, posljedica uporabe oružja za masovno uništenje, genetskih rekombinacija (koje mogu dovesti u pitanje budućnost ljudske vrste) ili, u najlakšem obliku, ekonomske krize globalnoga kapitalističkog sustava u jednom dijelu svijeta koja će prouzročiti krizu u cijelom svijetu (Gidens [Giddens], 1998 [1990]: 147; Ricer [Ritzer], 2009 [2006]: 205-209). Giddens će se vjerojatno s tim konstatacijama globaliziranog svijeta složiti, pa ga zato i zove »odbjegli svijet« pun anksioznosti i rizika. Međutim, iako proces globalizacije mijenja naš način života, Giddens je optimističan i smatra kako možemo naći način da ovladamo rizicima i naš »odbjegli svijet« stavimo pod kontrolu. U tom smislu, pozivajući se na Lascha, navodi četiri »adaptivne reakcije« na profil rizika modernosti (Gidens [Giddens], 1998 [1990]: 131-133). Pragmatičko prihvaćanje gledište je koje se fokusira na svakidašnje probleme i zadaće, u smislu uvjerenja da su mnogi događaju u suvremenom svijetu izvan naše kontrole. To je ambivalentno "preživljavanje« između pesimizma i kulture nade. Zadržani optimizam je vjerovanje u providnost razuma ili logiku koja će u zadnjem trenutku odvratiti od najgorega. To je uvjerenje da se ni u budućnosti neće dogoditi ono najgore. Cinični pesimizam posve je suprotan stav. To je uvjerenje da je anksioznost koju izazivaju rizici modernosti neposredno uključena. Cinizam je oblik umanjivanja emocionalnog utjecaja anksioznosti, tako što se na nju reagira putem humora ili različitih reakcija i odgovora. U slučaju modernosti, cinizam znači da ona nema perspektivu u budućnosti, a pesimizam da će, u svakom slučaju, modernost na kraju loše završiti. Radikalni angažman gledište je kojem se Giddens priklanja i u koje polaže najviše nade. To je stav mobilizacije i praktičkog suprotstavljanja, uglavnom putem društvenog pokreta, rizicima s teškim posljedicama kako bi ih se ukrotilo ili umanjilo. Svaka od tih adaptivnih reakcija ima za cilj osloboditi pojedinca od tereta anksioznosti za budućnost čovječanstva i pružiti mu toliko važnu »ontološku sigurnost«. 
Na koncu, čovjek nije gospodar povijesti, u smislu da bi je jednostavno mogao upotrijebiti za ostvarenje svojih kolektivnih ciljeva. Međutim, to ne znači da treba dići ruke od pokušaja upravljanja »Molohom«. Ako budemo pažljivi i pragmatični, postoje izgledi da ćemo izbjeći rizike koji prijete i da ljudsko društvo i nadalje napreduje, ističe Giddens. Ovdje je nužno uključiti i pojam refleksivnosti u izlaganju o riziku. Važnost rizika je u tome što je njihova prisutnost ključni uzrok stvaranja refleksivnosti na mikro, ali i na makro razini. Svijet koji je do te mjere izvan naše kontrole, na mikro planu zahtijeva veću razinu refleksivnosti i time ona postaje »ključnom« za čovjekov život. Možemo zaključiti da je suvremeno društvo opterećeno rizicima, opasnostima i neizvjesnostima. U »društvu rizika« (Beck) i »kulturi rizika« (Giddens) rizik je njezin strukturni element, sastavni dio suvremene civilizacije, u smislu da on nije izvana »nametnut«, nego da je tako inkorporiran u društvenu stvarnost da ga se teško prepoznaje kao izdvojeni entitet (Čaldarović, 1995: 245).

\section{7. »Radikalizirana modernost« $\mathrm{i}$ Giddensov odgovor postmodernistima}

$\mathrm{U}$ djelu The Consequences of Modernity, koje je bazična referenca ovoga rada, Giddens izlaže ideje »radikalizirane modernosti«, ${ }^{12}$ nasuprot već poznatim stajalištima postmodernističkih teoretičara poput Lyotarda, Baudrillarda, Derride, Harveya i Foucaulta. Naime, postmodernisti, pretežno francuski intelektualci, na početku inspirirani, a kasnije razočarani, marksističkom ideologijom, razmišljali su o implikacijama modernosti i dubokom iracionalizmu u kojem je zapala. Oni vjeruju da je prosvjetiteljstvo stiglo na kraj puta, da je svako znanje relativno, da su metapripovijesti opasne i da su »velike naracije« koje su dominirale do kraja pedesetih godina 20. stoljeća istrošene. Filozofski rečeno, emancipacija čovječanstva u prosvjetiteljstvu, teleologija duha $\mathrm{u}$ idealizmu i hermeneutika smisla $\mathrm{u}$ historicizmu (Butler, 2007 [2002]: 6, 11; Krivak, 2005: 103), kao bitne odrednice modernizma, više ne funkcioniraju u postmodernom društvu koje nastaje istodobno s postindustrijskim društvom. Dakle, postmodernost se zasniva na suprotstavljanju i kritici modernosti kao idejnom i praktičnom projektu

\footnotetext{
12 Pored radikalizirane, u sinonimnom značenju u svojim djelima Giddens koristi još $\mathrm{i}$ kasnu, zrelu, visoku i naprednu modernost. Sadašnji stadij razvoja modernog društva neki drugi sociolozi određuju kao druga modernost (Bek [Beck], 2001 [1986]), tekuća modernost (Bauman, 2011 [2000]), ali ne i kao postmodernost.
} 
koji je doživio kolaps i koga se, shodno tomu, treba osloboditi. To implicira da moderna Marxova, Weberova ili Durkheimova sociološka teorija, koja drži da je moguće dostići objektivnu istinu o društvu, ne može više imati privilegirano mjesto.

Postmodernistički mislioci kao sudionici »društva znanja« su uvidjeli višeslojne preobrazbe položaja i uloge znanja, odnosa znanja i moći te transformacije »znanja koje nije samo znanstveni, nego sve naglašeniji ekonomski i politički resurs« (Sofradžija, 2015: 13) u najrazvijenijim društvima, što se neposredno odražava na stanje kulture, vrijednosti i komunikacija »nakon promjena koje su utjecale na pravila igre u znanosti, književnosti i umjetnosti« (Lyotard, 2005 [1979[: V). U moderni su se znanja legitimirala metanaracijama, prema kojima postmodernisti izražavaju nepovjerenje zato što su većina njih poput bajki i kao takve gube ulogu legitimatora društvenih institucija, etike i sustava mišljenja. Zato su oni počeli gubiti vjeru u racionalističku misao, znanost i tehnologiju koje su, zbilja, prekoračile rubikon svoga djelokruga. ${ }^{13}$ Znanost u suvremenosti, lišena objektivnosti, etike i odgovornosti, zakazuje pred rastućim visokotehniziranim rizicima. Opasnosti nuklearnog rata, rizik genetskog inženjeringa, narušavanje svetosti života kloniranjem i eutanazijom te globalnoga industrijskog zagađivanja i kontaminacije životnih staništa ljudi, životinja i biljaka, zorno pokazuju da je u sprezi znanosti, tehnike, države i profita (Habermas, 2006 [2001]) prevladala makijavelistička logika po kojoj cilj opravdava sredstva. Tako je vrlo legitimno kritičko preispitivanje stare koncepcije modernističke vjere $\mathrm{u}$ znanost, tehniku i napredak. Zbog toga su postmodernisti doveli u sumnju postojeće sociološke teorije i nametnuli potrebu novih.

$\mathrm{S}$ tim se stajalištima neki sociolozi ne slažu, iako ne poriču da su mnoge moderne pojave izgubile smisao, da su se promjene nesumnjivo dogodile $i$ da ih je potrebno opisati, dati im novo značenje. Najglasovitiji među njima upravo je Giddens, koji smatra da su te promjene posljedica razvoja modernosti, a ne tranzicije $\mathrm{k}$ postmodernosti. ${ }^{14}$ On ne vjeruje da su te promjene toliko velike da bi se opravdala tvrdnja da postoji transformacija od modernog u postmoderno društvo, iako ne negira da bi se

13 »Cijela konstrukcija svijeta danas je u biti znanstveno-tehnička. [...] Tehnika je postala način koji omogućava svaki drugi odnos prema svijetu; tehničko djelovanje postalo je sudbinsko, u smislu da određuje naše djelovanje i življenje« (Sofradžija, 2015: 67).

${ }^{14}$ Giddens taj termin uvijek stavlja pod navodnike zato što drži da živimo u dobu radikalizirane modernosti. Mi ćemo, ipak, odstupiti od njegovog standarda. 
postmodernost u budućnosti mogla ostvariti (Haralambos i Holborn, 2002 [1995]: 1075; Coser, 2005 [1964]: 374). Štoviše, identificira osnovne obrise postmodernog poretka (postoskudični sustav, humanizacija tehnologije, višeslojna demokratska participacija i demilitarizacija) koji predstavlja kretanje »s one strane modernosti«. U načelu, Giddens odbacuje postmodernizam kao u filozofiji i društvenim znanostima neutemeljenu teoriju, zalaže se za ponovno razmatranje prirode modernosti i na kraju tvrdi da mi i dalje živimo u modernom svijetu, ali u njegovoj poznoj fazi. Predstavlja li Giddensova »radikalizirana modernost« nastavak procesa koji su već pokrenuti u modernom dobu još od vremena prosvjetiteljstva, jednu novu ili završnu fazu modernosti, ili pak ulazak u kvalitativno drugačiju epohu - postmodernu eru? On smatra da mi trenutačno ne živimo u postmodernosti, nego $\mathrm{u}$ dobu u kojem "posledice modernosti postaju radikalnije i univerzalnije nego što su bile ranije« (Gidens [Giddens], 1998 [1990]: 15). U »visokoj« ili »kasnoj« modernosti, odnosno »posttradicionalnom poretku« njene konzekvence se više nego prije univerzaliziraju i radikaliziraju, ali to Giddensa ne vodi prihvaćanju postmodernizma kao novog razdoblja ljudske povijesti, koje je potpuno odvojeno od obrazaca kulturnih i društvenih organizacija koje su nastale u modernoj epohi. To je njegov ključni argument odbacivanja postmodernosti. U dobu »kasne modernosti«, kad je svako znanje podložno preispitivanju i revidiranju, Giddens smatra da sociologija ima najvažnije mjesto te je stoga određuje kao »najopćenitiju vrstu refleksije o modernom društvenom životu« (Zlatar, 2008: 165). Kao takva, sociološka teorija o društvu diskurzivno-politički sudjeluje u oblikovanju društvenog poretka, jer je modernost po sebi »duboko $i$ imanentno sociologizovana« (Gidens [Giddens], 1998 [1990]: 49).

\section{Zaključak}

Moloh, taj »podivljali stroj«, kako ga Giddens naziva, prijeti da će se otrgnuti kontroli upravljanja i da će čovječanstvo završiti u nekoj vrsti autodestrukcije. I doista, Giddensovo »proročanstvo«, izloženo još devedesetih godina 20. stoljeća, više je nego ikada blizu ostvarenja. Kapitalizam je u sve većim proturječnostima, ideja kontinuiranog iscrpljivanja resursa ne zna za diskontinuitet, tehnološki ekspanzionizam u stalnoj je uzlaznoj putanji, zemlje posjednice oružja za masovno uništenje stalno provociraju nove sukobe, ulaganje $u$ moderno naoružanje u stalnom je usponu, a ekološka katastrofa sve ozbiljnije prijeti. Analitičari alarmiraju da bi modernost u budućnosti, odnosno postmo- 
dernost, mogla biti katastrofalna, dok god se ulaže i daje primat tehnici u odnosu na čovjeka i humane vrijednosti i dok god se »stimulira« proizvodnja rizika naspram proizvodnje sigurnosti. »Rizičnost će zato vjerojatno ostati trajnim obilježjem naše civilizacije« (Cifrić, 1994: 31). Paradoksalno, odgovornost za teške posljedice globalnih rizika koje je proizvela modernost, a koje cjelokupno čovječanstvo trpi, Giddens se ne usuđuje adresirati na nekog pojedinca, skupinu, zemlju, savez, kontinent ili kulturu. On eksplicitno ističe da »nijedna posebna osoba ili grupa nije za te posledice odgovorna, niti se od nje zahteva da 'dovede stvari u red'" (Gidens [Giddens], 1998 [1990]: 128). Ovdje je teško složiti se s njim i ne parafrazirati Gadamera, koji kaže da živimo u »doba anonimne odgovornosti« (Sofradžija, 2015: 15). Ako pogledamo disbalanse između bogatih i siromašnih, moćnih i slabih, Zapada i Istoka, Sjevera i Juga, nije teško uočiti da je mnogo veća odgovornost na prvima. Oni su drugi pasivni sudionici ili nerijetko samo nijemi promatrači i puke žrtve. Bez obzira na različite projekcije alternativnih budućnosti mnogih postmodernih autora, moderni sekularizirani čovjek, koji se isključivo vodi logikom dominacije, koji je »zaboravio Boga» (Nasr, 2001 [1968]: 193) i krajnji uzrok stvari, koji je »desakralizirao prirodu« i nemilosrdno njome ovladao, zanemarujući sve osim ekonomskih motiva, pa i vrijednost života, izgubio je kompas i traga za novim paradigmama.

Međutim, pojedinci, koliko god se trudili, suvremene rizike ne mogu ukrotiti. Potreban je jedan drukčiji, sveobuhvatni sistematski pristup, radikalan zaokret u filozofiji života današnjeg čovjeka, ne samo spram sebe, nego i prema pripadnicima vlastite vrste i cjelini svijeta u kojem obitava (Žiga, 2012: 48). Nije dostatno baviti se posljedicama i okolnostima koje su do moderne krize dovele, ukoliko se prije toga ne pozabavimo uzrocima i samim čovjekom i njegovom multidimenzionalnošću. Ovdje je zgodno referirati se na jednog od najmeritornijih suvremenih muslimanskih kritičara moderne znanosti, Seyyed Hossein Nasra, jednako kritičnog prema »imperijalnom Zapadu« i »raspalom Istoku«. On je mišljenja da u susretu modernog tehniziranog čovjeka s prirodom leži odgovor na krizu modernosti. Nasr ne misli da je samo ekološki problem izazov za čovječanstvo. Po njemu, moderna sekularizirana znanost razvijena od prosvjetiteljstva naovamo predstavlja još veći izazov. Ona je razvrgnula savez sa svetim i etičkim principima i svojim monopolističkim i totalitarnim pretenzijama prijeti egzistenciji ljudskog roda. (Nasr, 2001 [1968]: 194). »Nasr napada trijumfalizam moderne znanosti i njen prometejski i titanski karakter koji se 
naročito razvio na Zapadu od Dekarta naovamo. Osebujno biće čovjekovo nastoji se svesti i reducirati samo na ono što čovjek zna! Pritom se zanemaruju ostale dimenzije ljudskoga bića, a čovjeka tjera da postane puko zemaljsko i za Zemlju prikovano biće! Prestao je biti biće koje je zagledano u dubine nebeskog plavetnila i koje se pita šta je tamo iza zvjezdane zavjese« (Karić, 2001: 214-215).

Premda ne dijeli u potpunosti takva stajališta, Giddens, potaknut idejama brojnih neomarksističkih teoretičara, veliku nadu pridaje različitim društvenim pokretima - prije svega radničkom. Radnički pokret, kao glavna "prijetnja« tržišnom sustavu, svojim radikalnim idejama i masovnošću može »radikaliziranu modernost« preobraziti u jedan humaniji, pravedniji i sigurniji društveni poredak. Sistemske tehnike nadzora moderne države polučile su, u stanju svoje ugroženosti, pokrete za slobodu i demokraciju koji su sve snažniji širom svijeta. Mirovni i ekološki pokreti su nastali na isti način, iako predstavljaju jedan noviji sociološki fenomen. Uspon pacifističkih i antinuklearnih pokreta nakon Drugoga svjetskog rata, predstavljao je tračak nade da bi mir mogao postati globalni fenomen koji bi svoj izraz imao u vrijednostima tolerancije i slobode. Do globalnih razmjera ugrožen okoliš proizveo je ekološka svijest pa potom ekološke pokrete za zaštitu narušene životne sredine, uslijed sve veće industrijalizacije modernog društva. Ekološki će pokreti kasnije postati i politički pokreti (stranke zelenih), redovito zastupljeni u mnogim europskim parlamentima (Pavlović, 2009: 199-256). U studiji koja se bavi identifikacijom gospodarske i društvene inovativne politike Europe, Europe in the Global Age (Gidens [Giddens], 2009 [2007]), u procesu »promjena načina života« Giddens zagovara »ekološku modernizaciju«, tj. razvoj novih »ekoloških tehnologija« i obnovljivih izvora energije. Smatra da je potreban inovativni reformski pristup u smanjenju korištenja fosilnih goriva i podizanje ekoloških, klimatskih i energentskih problema na međunarodnu razinu. I ovoga puta velike nade polaže u civilno društvo i skupine građana čiji bi pritisak na vlade i korporacije pridonio ojačavanju svijesti o prirodnom okruženju. Drugi korak koji predlaže jest zamjena velikog broja proizvoda uslugama (iznajmljivanje, dematerijalizacija, funkcionalni sustavi) kako bi se smanjila potrošnja energije i materijalnih sredstava (Gidens [Giddens], 2009 [2007]: 200).

Još jedan od načina da se umanje mnogobrojni rizici suvremenog svijeta, osobito kad su posrijedi rizici s teškim i uništavajućim posljedicama, kao što je potencijalni nuklearni sukob globalnih razmjera ili mogućnost 
ekološke katastrofe prema Giddensu je projektiranje alternativnih budućnosti, tj. stvaranje modela »utopijskog realizma«, pod kojim podrazumijeva globalnu preraspodjelu materijalnog bogatstva, demilitarizaciju, humanizaciju tehnologije i izraženiju demokratsku participaciju. To su osnovne crte postmodernog poretka koje nagovještavaju njegovo ostvarenje jednom $u$ budućnosti. Giddensova vizija postmodernog društva, kao kvalitativno novog društvenog poretka, koji još nije ostvaren, ali koji će se u budućnosti vjerojatno ostvariti jest, kako i sam priznaje, idealistička. Četiri navedene promjene koje će se, po njegovom predviđanju, dogoditi u budućnosti, u procesu preobrazbe modernosti u postmodernost, jesu u najmanju ruku diskutabilne, kao što već i sama postmodernost kod nekih kritičara izaziva razočarenje. Zato se sve angažiranije govori o intelektualnim strujama koje se pojavljuju kao alternative postmodernosti, čije je razdoblje najvećeg utjecaja prošlost, kao što je angloamerička liberalna struja koju predstavljaju John Rawls, Michael Sandel, Joseph Raz, Amy Guttman, Will Kymlicka i drugi. $\mathrm{Na}$ koncu, postmodernističku misao i praxis valja shvatiti kao dobru »moralnu opomenu« razularenom svijetu, ali obavezno »u sklopu interakcije s ostalim misaonim tokovima« (Butler, 2007 [2002]: 123).

Ako znamo da su pesimizam, sumnja i racionalna kritička misao supstancijalni dio postmodernističke misli, posve je razložno da se Giddensove kozmopolitske ideje podvrgnu istom postupku. ${ }^{15}$ Iako je ovaj rad prije svega preglednoga, a ne kritičkog karaktera, treba naglasiti kako je teško povjerovati da će se bogate industrijske zemlje u doglednoj budućnosti olako pomiriti s padom životnog standarda i "globalnom redistribucijom bogatstva « i da će akumulirani kapital podijeliti sa siromašnim i nerazvijenim zemljama, uključujući mnoge afričke zemlje. Teško je racionalnom čovjeku prihvatiti Giddensov pojam demilitarizacije, gdje će industrijske zemlje smanjiti troškove za naoružanje i ratovanje. Posljedično, Giddensova vizija humanizacije tehnologije nema izglednih osnova, jer nuklearni sukob globalnog ratovanja ostaje ozbiljna i uvijek otvorena opasnost od koje bi stradale i sukobljene i neutralne strane. Načelo razoružanja među vojnim silama ostaje mrtvo slovo na papiru. Možda su Giddensove namjere plemenite, ali nam se one ipak, barem u ovom trenutku, čine krajnje iluzornim i neostvarivim. Zato je Beck u pravu kad tvrdi da je rizično

${ }^{15}$ Giddens je vrlo sustavno izložio viziju »globalnoga kozmopolitskog društva« u djelu Odbjegli svijet (Gidens [Giddens], 2005 [2000]), koje je svojevrsni uvod u raspravu o globalizaciji i njezinim implikacijama na društvo u kojem se razvija. 
društvo katastrofično društvo, u kome izvanredno stanje prijeti da postane normalno stanje (Beck, 2001 [1993]: 114).

Svojim analizama, idejama i teorijama Giddens je privukao simpatije velikog broja sljedbenika. Kao javni intelektualac, vrlo angažiran u društvenom i političkom životu Ujedinjenog Kraljevstva, također je bio predmet znanstvene kritike. Premda je kritičke literature o njegovim teorijama u izobilju, mi ćemo se, u ovim zaključnim mislima, ograničiti na američkog sociologa Jeffrey Alexandera (1996) koji je analizirao odnos tradicije i modernosti. Giddensova »radikalizirana modernost« je, prema njemu, vrlo generalizirana i radikalno kritična prema tradiciji i svim njezinim vrijednostima i normama. Jedan takav kritičan odnos prema samoj modernosti i njezinu birokratizmu kod Giddensa nedostaje. Istina, Giddens ne osporava važnost tradicije, on je čak brani od prosvjetiteljstva. Ipak, on je samo svodi na puku naviku i minimalizam kojem se pribjegava samo kad to zatreba. Moderno društvo je refleksivno, i kao takvo nezavisno od tradicije, stav je Giddensa. Alexander mu, isto tako, zamjera što vrlo pojednostavljeno definira dualizam »tradicije i modernosti«. Za Giddensa, modernost je uvijek u suprotnosti s tradicijom. Kritičari odgovaraju da to ne mora uvijek biti tako zato što postoje »nadindividualne kulturne forme koje karakteriziraju sva društva« (Zlatar, 2008: 177). Kritika koja obuhvaća različite teorijske aspekte Giddensova djela još uvijek ostaje otvorenom za druge sociološke analize i rasprave, budući da se njegov koncept modernosti specifično odnosi na suvremenu zapadnu civilizaciju. Usto, »radikalizirana modernost « i globalizacija društvenog života su procesi koji traju, odnosno koji još nisu završeni. ${ }^{16}$ Za suvremeni društveni život će i ubuduće modernost i rizik kao njegov strukturni element, imati ozbiljnu tendenciju globaliziranja i difuzije u svim dijelovima svijeta. Ipak, izložene kritike nimalo ne umanjuju Giddensov globalni akademski doprinos općenito sociologiji i važnost njegova mjesta u sociologiji modernosti i promišljanju njezinih institucija.

\section{LITERATURA}

Alexander, Jeffrey (1996). »Critical Reflections on 'Reflexive Modernization'«, Theory, Culture and Society, 13 (4): 133-138.

Bauman, Zygmunt (2011 [2000]). Tekuća modernost. Zagreb: Pelago.

${ }^{16}$ Društveni filozofi poput Habermasa i Touraina vjeruju da se »nedovršena moderna« nalazi u krizi, ali da se, usprkos tome, može i mora braniti. 
Beck, Ulrich (2001 [1993]). Pronalaženje političkog: prilog teoriji refleksivne modernizacije. Zagreb: Jesenski i Turk.

Beck, Ulrich (2003 [1997]). Što je globalizacija? Zagreb: Vizura.

Bek, Ulrih [Beck, Ulrich] (2001 [1986]). Rizično društvo: u susret novoj moderni. Beograd: Filip Višnjić.

Butler, Christopher (2007 [2002]). Postmodernizam. Sarajevo: Šahinpašić.

Cifrić, Ivan (1994). Napredak i opstanak: moderno mišljenje u postmodernom kontekstu. Zagreb: Hrvatsko sociološko društvo.

Coser, Lewis (2005 [1964]). Teoritë sociologjike [Sociological Theory]. Tirana: Plejad.

Čaldarović, Ognjen (1995). Socijalna teorija i hazardni život: rizici i suvremeno društvo. Zagreb: Hrvatsko sociološko društvo i Zavod za sociologiju.

Fuko, Mišel [Foucault, Michel] (1997 [1975]). Nadzirati i kažnjavati: rođenje zatvora. Beograd: Prosveta.

Fuko, Mišel [Foucault, Michel] (2005 [1978]). Rađanje biopolitike. Novi Sad: Svetovi.

Giddens, Anthony (1991). Modernity and Self-Identity: Self and Society in the Late Modern Age. Cambridge: Polity Press.

Giddens, Anthony (1992). The Transformation of Intimacy: Sexuality, Love and Eroticism in Modern Societies. Stanford: Stanford University Press.

Giddens, Anthony (1994). »Living in a Post-Traditional Society«, u: Ulrich Beck, Anthony Giddens i Scott Lash (ur.). Reflexive modernization: Politics, tradition and aesthetics in the modern social order. Cambridge: Polity Press.

Gidens, Entoni [Giddens, Anthony] (1998 [1990]). Posledice modernosti. Beograd: Filip Višnjić.

Gidens, Entoni [Giddens, Anthony] (2005 [2000]). Odbegli svet. Beograd: Stubovi kulture.

Gidens, Entoni [Giddens, Anthony] (2007 [2006]). Sociologija. Beograd: Ekonomski fakultet.

Gidens, Entoni [Giddens, Anthony] (2009 [2007]). Evropa u globalnom dobu. Beograd: Clio.

Habermas, Jürgen (2006 [2001]). Budućnost ljudske prirode: prema liberalnoj eugenici? Vjerovanje i znanje. Zagreb: Naklada Breza.

Haralambos, Michael i Holborn, Martin (2002 [1995]). Sociologija: teme i perspektive. Zagreb: Golden marketing.

Held, David i Thompson, John B. (ur.) (1989). Social Theory of Modern Societies: Anthony Giddens and his Critics. Cambridge: Cambridge University Press.

Karić, Enes (2001). »Nasr - mislilac svetog«, u: Seyyed Hossein Nasr. Susret čovjeka i prirode. Sarajevo: El-Kalem, str. 209-223.

Krivak, Marijan (2005). »Pogovor«, u: Jean-François Lyotard. Postmoderno stanje: izvještaj o znanju. Zagreb: Ibis grafika, str. 101-108.

Loyal, Steven (2003). The Sociology of Anthony Giddens. London: Pluto Press.

Lyotard, Jean-François (2005 [1979[). Postmoderno stanje: izvještaj o znanju. Zagreb: Ibis grafika.

Meštrović, Stjepan G. (1998). Anthony Giddens: The Last Modernist. New York: Routledge. 
Nasr, Seyyed Hossein (2001 [1968]). Susret čovjeka i prirode. Sarajevo: El-Kalem. Neš, Kejt [Nash, Kate] (2006 [2000]). Savremena politička sociologija: globalizacija, politika i moć. Beograd: Službeni glasnik.

Pajaziti, Ali (2009). Fjalor i sociologjisë [Sociološki rječnik]. Skopje: Logos-A.

Pavlović, Vukašin (2009). Društveni pokreti i promene. Beograd: Službeni Glasnik i Zavod za udžbenike i nastavna sredstva.

Ricer, Džordž [Ritzer, George] (2009 [2006]). Savremena sociološka teorija i njeni klasični koreni. Beograd: Službeni glasnik.

Sofradžija, Halima (2015). Hiperpolitika i savremeno društvo: proces tehniziranja svijeta. Sarajevo: Fakultet političkih nauka.

Tarifa, Fatos (2013). »Parathënie për botimin shqip«, u: Anthony Giddens. Pasojat e modernitetit. Tirana: UET Press, str. IX-XXIII.

Thomson Reuters (2009). Humanities citation ranking. http://www.eoht.info/page/ Humanities+citation+ranking.

Touraine, Alain (2007 [1992]). Kritika modernosti. Zagreb: Politička kultura.

Turza, Karel (1998). Luis Mamford - jedna kritika modernosti. Beograd: Zavod za udžbenike i nastavna sredstva.

Volerstin, Imanuel [Wallerstein, Immanuel] (2005 [2004]). Uvod u analizu svetskog sistema. Cetinje: OKF.

Zlatar, Jelena (2008). »Anthony Giddens: refleksivna projekcija osobnosti«, Revija za sociologiju, 39 (3): 161-182.

Žiga, Jusuf (2012). Vrijeme (sve)politike: iluzije savremenog ekologizma. Sarajevo: BZK Preporod.

\title{
The Concept of Modernity in the Work of Anthony Giddens
}

\author{
Elmir KARADŽl \\ Prizren, Kosovo \\ karadzi82@hotmail.com
}

In this paper the author deals with social discourses of modernity as a principal concept of sociological theory. His aim was to indicate the fundamental postulates of modern society by referring to the concept of modernity as laid out by Anthony Giddens in his work when analysing a multitude of changes in society, economics, politics, culture, religion, science and technology in the past few centuries. In the first part of the paper, the author presented the elementary features of pre-modern and modern society contrasted by tradition and modernity and the rise of an essentially different way of perceiving and organising social life. Then he proceeds to the main characteristics of contemporary multidimensional social orders concerning the speed and width of transformation. This is followed by the author's reference to the main characteristics of modern, multidimensional social 
orders in terms of the dynamics and extent of change. Giddens' fundamental theoretical concepts of modernity are laid out next: the phenomenology of modernity, insecurity and the risks of the management of the "Moloch" of modernity and the term "radicalised modernity". The latter concept was used by Giddens to challenge the postmodernist interpretation of society in terms of uselessness of the "great narratives" and the transformation from modern to postmodern society. Concluding remarks summarised analytically and critically Giddens' innovative projections of "utopian realism" and his vision of postmodernity.

Key words: Giddens, modernity, tradition, reflexivity, globalisation, risk, radicalised modernity, postmodernity 